\title{
PRZESŁANKI ORZEKANIA IZOLACJI POSTPENALNEJ ROZWAŻANIA NA TLE ORZECZNICTWA SĄDÓW POWSZECHNYCH I SĄDU NAJWYŻSZEGO
}

\begin{abstract}
Streszczenie. Przedmiotowa ustawa wprowadziła do polskiego porządku prawnego instytucję izolacji postpenalnej. Regulacja ta jeszcze na etapie prac legislacyjnych była szeroko krytykowana przez środowiska naukowe jako wprowadzona pospiesznie i w sposób nieprzemyślany. Zarzucano jej, że stanowiła jedynie odpowiedź na społeczne zapotrzebowanie, wynikające z obawy przed opuszczeniem zakładów karnych przez sprawców najcięższych przestępstw, którzy kończyli odbywanie kary 25 lat pozbawienia wolności. Wątpliwości doktryny koncentrowały się wokół sposobu określenia zakresu podmiotowego ustawy. Wskazywano, że jest on nieprecyzyjny i budzi zasadnicze wątpliwości interpretacyjne, co skutkować może odnoszeniem jej postanowień do zbyt szerokiego kręgu adresatów. Analiza orzecznictwa sądów powszechnych i Sądu Najwyższego wskazuje jednak, że regulacja stosowana jest z ostrożnością, a sądy wykorzystują istniejące możliwości procesowe, wynikające $\mathrm{z}$ trybu nieprocesowego postępowania cywilnego w celu zapobiegania nieuprawnionej ingerencji w wolność człowieka oraz jego status jako podmiotu prawa.
\end{abstract}

Slowa kluczowe: izolacja postpenalna, zasada dostatecznej określoności przepisów prawa, przymusowa internacja sprawców przestępstw, prawo konstytucyjne, przestępstwa przeciwko życiu, zdrowiu i wolności seksualnej innych osób.

\section{WSTĘP}

Ustawa z dnia 22 listopada 2013 roku o postępowaniu wobec osób z zaburzeniami psychicznymi stwarzających zagrożenie życia, zdrowia lub wolności seksualnej innych osób (Dz.U. z 2014 r., poz. 24; dalej: ustawa o izolacji postpenalnej, ustawa) została uchwalona w odpowiedzi na zbliżające się zakończenie wykonywania kar orzeczonych wobec sprawców najcięższych przestępstw, którym wymierzoną karę śmierci zamieniono na karę 25 lat pozbawienia wolności (ustawa z dnia 7 grudnia 1989 r. o amnestii, Dz.U. z 1989 r. Nr 64, poz. 390, art. 7 ust. 3). $Z$ uzasadnienia ustawy o izolacji postpenalnej wynika, że jej celem było uzupełnienie polskiego porządku prawnego o rozwiązania przewidujące izolacyjną terapię sprawców przestępstw, którzy, m.in. mając zaburzenia psychiczne

*Uniwersytet Łódzki, Wydział Prawa i Administracji, franciszek.jedras@gmail.com.

${ }^{* * *}$ Uniwersytet Łódzki, Wydział Prawa i Administracji, Katedra Prawa Konstytucyjnego, katarzyna.j.grabarczyk@gmail.com. 
w postaci upośledzenia umysłowego, zaburzenia osobowości lub zaburzenia preferencji seksualnych, mogą popełnić ponowne przestępstwo przeciwko życiu, zdrowiu, bezpieczeństwu powszechnemu lub wolności seksualnej innych osób (Uzasadnienie projektu ustawy, 1-2). Ustawodawca wprowadzając przedmiotową regulację, dążył do umożliwienia sprawcom pozbawionym wolności readaptacji do funkcjonowania w społeczeństwie i efektywnego monitorowania zachowania sprawców przebywających na wolności (Uzasadnienie projektu ustawy, 2). Projekt ustawy jeszcze na etapie prac legislacyjnych stanowił przedmiot ożywionej dyskusji doktryny prawa konstytucyjnego i prawa karnego, która w jego realizacji dopatrywała się nie chęci uzupełnienia stanu prawnego o nowy środek zabezpieczający, lecz przejawów populizmu prawniczego i działania pod presją społeczną oraz medialną (zob. Bocheński 2014). Konsultacje społeczne prowadzone były pospiesznie, a zgłaszane wątpliwości i sygnalizowane problemy nie spotkały się z uznaniem i należną refleksją, w znakomitej większości nie zostały uwzględnione (Opinia Polskiego Towarzystwa Psychologicznego).

Przedmiotem krytyki, oprócz trybu procedowania nad ustawą, powiązania tego aktu z prawem karnym przy jednoczesnym nieposzanowaniu naczelnych zasad tej gałęzi prawa, które mają charakter gwarancyjny wobec praw i wolności jednostki, był sposób określenia kręgu podmiotowego ustawy.

\section{PRZESLANKI STOSOWANIA IZOLACJI POSTPENALNEJ ORAZ ZWIĄZANE Z NIMI WĄTPLIWOŚCI INTERPRETACYJNE}

Zgodnie $\mathrm{z}$ art. 1 ustawa o izolacji postpenalnej reguluje postępowanie wobec „osób stwarzających zagrożenie”, które spełniają łącznie następujące przesłanki:

1) odbywają prawomocnie orzeczoną karę pozbawienia wolności lub karę 25 lat pozbawienia wolności, wykonywaną w systemie terapeutycznym;

2) w trakcie postępowania wykonawczego występowały u nich zaburzenia psychiczne w postaci upośledzenia umysłowego, zaburzenia osobowości lub zaburzenia preferencji seksualnych;

3) stwierdzone $u$ nich zaburzenia psychiczne mają taki charakter lub takie nasilenie, że zachodzi co najmniej wysokie prawdopodobieństwo popełnienia czynu zabronionego z użyciem przemocy lub groźbą jej użycia przeciwko życiu, zdrowiu lub wolności seksualnej, zagrożonego karą pozbawienia wolności, której górna granica wynosi co najmniej 10 lat.

Doktryna prawa karnego, analizując przytoczoną normę prawną, wskazywała, że zakres podmiotowy ustawy określony jest bardzo szeroko. W konsekwencji przepisy ustawy wobec jego nieograniczenia znajdą zastosowanie nie tylko w stosunku do najgroźniejszych przestępców, lecz także do „bardzo szerokiej grupy sprawców przestępstw powszechnych" (Płatek 2003, 47). Monika Płatek podkreślała, że do zawężenia kręgu jej adresatów nie doprowadzi przesłanka związana 
z istnieniem „bardzo wysokiego prawdopodobieństwa popełnienia czynu zabronionego", ma ona bowiem charakter bardzo niejasny i nieprecyzyjny. Ustawa nie przewiduje żadnych kryteriów umożliwiających dokonanie tego rodzaju oceny (Płatek 2003, 49). Pogląd ten spotkał się z uznaniem Ryszarda Piotrowskiego, który, podzielając te zastrzeżenia, odniósł je także do normy art. 14 ust. 3 ustawy o izolacji postpenalnej, określającej podstawy orzekania o umieszczeniu w Krajowym Ośrodku Zapobiegania Zachowaniom Dyssocjalnym (dalej: Ośrodek) albo o nadzorze prewencyjnym. Norma ta nakłada na sąd orzekający na podstawie ustawy obowiązek dokonania rozróżnienia przesłanki „,wysokiego prawdopodobieństwa” popełnienia przestępstwa oraz „bardzo wysokiego prawdopodobieństwa" popełnienia przestępstwa i, w oparciu o nie, dokonania wyboru stosowanego środka. W jego ocenie niedookreślony charakter samych przesłanek oraz niewskazanie kryteriów, umożliwiających ich rozróżnienie, łącznie czynią rolę sądu fikcyjną i prowadzą do przekazania kognicji w przedmiocie orzeczenia internacji jednostek biegłym psychiatrom i psychologom (Piotrowski 2013, 38).

Istotne zastrzeżenia wobec ustawy o izolacji postpenalnej formułował także Marek Domański, zwracając uwagę na charakter zaburzeń psychicznych w postaci upośledzenia umysłowego, zaburzenia osobowości lub zaburzenia preferencji seksualnych oraz moment czasowy ich wystąpienia. Redakcja przepisu sugerowała, że zaburzenia te ujawniły się dopiero w czasie wykonywania orzeczonej już kary pozbawienia wolności. W ocenie Domańskiego przyjęcie takiego poglądu jest nieuprawnione; zaburzenia psychiczne pojawiają się u sprawców przestępstw wcześniej, jeszcze na etapie rozwoju osobowości i są diagnozowane w momencie przypisywania sprawcy odpowiedzialności karnej, na etapie postępowania przygotowawczego, w toku weryfikowania poczytalności jednostki (Domański 2013, 19-20).

Ustawę krytykowało również środowisko psychiatrów, psychologów i seksuologów. Janusz Heitzman wskazywał, że regulacja nakłada na biegłych sądowych obowiązki, które przekraczają ich kompetencje, polegające nie tylko na przeprowadzaniu badania medycznego, dokonania rozpoznania oraz określenia jego konsekwencji, ale także sprowadzają się do ,postawienia paradygmatu, że osoba badana, z wysokim prawdopodobieństwem popełni czyn zabroniony podobny do tego, za który została wcześniej skazana" (Heitzman 2013, 10). W ocenie Heitzmana prowadzi to do przeniesienia odpowiedzialności za internację jednostek na biegłych psychiatrów (Heitzman 2013, 11). Sam cel utworzenia Ośrodka uznał on za fasadowy, podkreślając, że w jego ocenie jedynym ratio legis regulacji jest izolacja osób stwarzających zagrożenie, nie zaś ich leczenie (Heitzman 2013, 27). Trudno bowiem oczekiwać, by po odbyciu kary pozbawienia wolności w systemie terapeutycznym, które nie doprowadziło do poprawy stanu zdrowia jednostki, ta ponownie wyraziła chęć i zauważyła potrzebę poddania się działaniom terapeutycznym (Heitzman 2013, 10). Tak sformułowane zarzuty, kierowane w toku postępowania legislacyjnego do przepisów określających 
krąg podmiotowy ustawy, uzasadniają refleksję nad realizacją przez nią rygorów zasady dostatecznej określoności przepisów prawa, wynikającej z zasady demokratycznego państwa prawnego, oraz próbę dokonania oceny reakcji organów stosowania prawa na wskazane niedostatki ustawy.

\section{KONSTYTUCYJNA ZASADA OKREŚLONOŚCI PRZEPISÓW PRAWA I ZWIĄZANE Z NIĄ RYGORY STANOWIENIA PRAWA KARNEGO}

W pierwszej kolejności wskazać należy, że zasada dostatecznej określoności przepisów prawa stanowi jedną z zasad prawidłowej legislacji, wywodzoną z zasady ochrony zaufania do państwa i stanowionego przez nie prawa (Sokolewicz, Zubik 2016, 146). Wyraża ona nakaz formułowania przepisów prawa w sposób jasny, poprawny i precyzyjny (Zalasiński 2008, 192). Genezy zasady dostatecznej określoności doktryna prawa konstytucyjnego poszukuje dwutorowo, w koncepcji państwa prawnego, wyrażonej w art. 2 Konstytucji Rzeczypospolitej Polskiej z dnia 2 kwietnia 1997 roku (Dz.U. z 1997 r. Nr 78, poz. 483; dalej: Konstytucja) oraz w tych przepisach ustawy zasadniczej, które mają charakter gwarancyjny w stosunku do praw i wolności, np. w art. 31 ust. 3 Konstytucji i art. 42 ust. 1 Konstytucji, dopuszczających ograniczenia w zakresie praw i wolności obywatelskich, warunkując ich wprowadzenie m.in. zachowaniem przez nie formy aktu rangi ustawowej (Zalasiński 2008, 190).

Zasady określoności nie należy sprowadzać jedynie do „zakazu tworzenia prawa na tyle nieprecyzyjnego, by mogło stać się podstawą nieuzasadnionego naruszania praw jednostki, ale także nakazu (w sensie pozytywnym) tworzenia prawa zrozumiałego dla jednostki" (wyr. TK z dnia 24 czerwca 2008 r., SK 16/06, OTK ZU-A 2008, nr 5, poz. 85). Przepisy prawa winny charakteryzować się „precyzyjnością", polegającą na jednoznaczności w ustaleniu ich znaczenia i wskazaniu skutków prawnych, ,jasnością", czyli zrozumiałością dla adresatów, a także „poprawnością" rozumianą jako spełnienie wymogów co do technicznej strony legislacyjnej (wyr. TK z dnia 10 listopada 1998 r., K 39/97, OTK ZU 1998, nr 6, poz. 99).

Trybunał wymaga także, by przepisy prawne były konstruowane poprawnie z punktu widzenia językowego i logicznego, uznając jednocześnie, że dopiero spełnienie tego warunku, mającego charakter podstawowy, pozwala na jego ocenę w aspekcie pozostałych kryteriów. Adresaci regulacji prawnych mogą oczekiwać od racjonalnego ustawodawcy

stanowienia norm prawnych niebudzących wątpliwości co do treści nakładanych obowiązków i przyznawanych praw. Precyzja przepisu winna przejawiać się w konkretności nakładanych obowiązków i przyznawanych praw tak, by ich treść była oczywista i pozwalała na wyegzekwowanie (wyr. TK z dnia 21 marca 2001 r., K 24/00, OTK ZU 2001, nr 3, poz. 51). 
W kontekście przepisów prawnych, które wpływają na status prawny jednostki, trybunał nakazuje bardziej restrykcyjne podejście do realizacji zasady określoności (Zalasiński 2008, 198-199), wymagając, by każdy przepis tworzący prawa lub nakładający obowiązki pozwalał jednoznacznie ustalić, kto, kiedy i w jakiej sytuacji staje się adresatem, aby możliwa była jego jednolita wykładnia i stosowanie oraz by zakres jego zastosowania obejmował tylko te sytuacje, w których działający racjonalnie ustawodawca istotnie zamierzał wprowadzić regulację tworzącą prawa lub obowiązki (wyr. TK z dnia 24 lutego 2003 r., K 28/02, OTK ZU-A 2003, nr 2, poz. 13).

Zasada określoności przepisów prawa nabiera wyjątkowego znaczenia na gruncie prawa karnego (represyjnego) ze względu na jego gwarancyjną rolę przy zapewnieniu ochrony prawnej jednostek przed ,,arbitralnością oraz nadużyciami ze strony organów władzy publicznej, w tym przed «dowolnością orzekania i sposobu wykonywania następstw czynów zabronionych, niewspółmierności tych następstw do winy i karygodności czynu»" (wyr. TK z dnia 22 czerwca 2010 r., SK 25/08, OTK ZU-A 2010, nr 5, poz. 51).

Chociaż na obszarze prawa karnego zasada określoności ma szczególne znaczenie, to jednak nie wyklucza ona posługiwania się przez ustawodawcę klauzulami generalnymi lub pojęciami niedookreślonymi, których nie da się całkowicie wyeliminować z przepisów obowiązującego prawa, a których znaczenie kształtuje się w procesie sądowej wykładni prawa i stosowania tych przepisów, zapewniając jednocześnie obywatelom gwarancję bezpieczeństwa prawnego.

\footnotetext{
Posługiwania się w prawie [...] pojęciami nieostrymi nie można a priori traktować jako uchybienia legislacyjnego. Często bowiem skonstruowanie określonej normy prawnej przy ich pomocy stanowi jedyne rozsądne wyjście. Na straży właściwego zastosowania takiej normy stoją przede wszystkim normy procesowe, nakazujące wykazanie przesłanek, jakie legły u podstaw zastosowania w konkretnej sprawie normy prawnej skonstruowanej przy użyciu tego rodzaju nieostrego pojęcia (uchw. TK z dnia 6 listopada 1991 r., W 2/91, OTK ZU 1991, poz. 20),
}

a „brak dostatecznej precyzji i niejasność regulacji może być samoistną podstawą orzeczenia niekonstytucyjności przepisu tylko wówczas, gdy nie jest możliwe ustalenie jego treści w drodze wykładni. Orzeczenie tej treści stanowi zatem środek o charakterze ultima ratio" (zob. post. TK z dnia 27 kwietnia 2004 r., P 16/03, OTK ZU-A 2004, nr 4, poz. 36; wyr. TK z dnia 16 grudnia 2003 r., SK 34/03, OTK ZU-A 2003, nr 9, poz. 102).

Przepis może być pozbawiony mocy obowiązującej z powodu jego niejasności tylko w ostateczności, gdy jego niedookreśloność nie może zostać zrekompensowana właściwą interpretacją w orzecznictwie sądowym. Nieokreśloność nie oznacza przyzwolenia na daleko idącą swobodę wykładni, która sprowokowałaby pojawienie się wątpliwości w odniesieniu do zakresu jego zastosowania oraz prawnokarnej kwalifikacji aktywności jednostki (zob. wyr. TK z dnia 22 czerwca 2010 r., SK 25/08, OTK ZU-A 2010, nr 5, poz. 51). 


\section{WĄTPLIWOŚCI DOKTRYNY PRAWA KONSTYTUCYJNEGO I PRAWA KARNEGO A PROCES SĄDOWEGO STOSOWANIA USTAWY}

Wskazane wątpliwości, związane z określonością przesłanek stosowania izolacji postpenalnej, uzasadniają analizę wydanego na jej podstawie dotychczasowego orzecznictwa sądów powszechnych oraz Sądu Najwyższego z kilku perspektyw.

Rozważyć należy w pierwszej kolejności, w jaki sposób sądy meriti prowadzą w tych sprawach postępowanie dowodowe, jaki wpływ na ich aktywność ma ograniczenie zasady kontradyktoryjności, wynikające z powierzenia orzekania $\mathrm{w}$ przedmiocie izolacji postpenalnej sądom cywilnym w trybie postępowania nieprocesowego oraz jaką wagę, przy dochodzeniu do prawdy materialnej, przypisują one dopuszczaniu i przeprowadzaniu dowodu z opinii biegłych. Analizy wymagają ponadto okoliczności, które są uznawane przez biegłych i następnie przez sądy orzekające w sprawie za uzasadniające przekonanie o istnieniu wysokiego albo bardzo wysokiego prawdopodobieństwa popełnienia czynu zabronionego wobec podejmowanych przez sądy prób definicji tych pojęć. Uwagę poświęcić należy także ogólnym dyrektywom interpretacyjnym, formułowanym przez Sąd Najwyższy zarówno przed wyrokiem Trybunału Konstytucyjnego, potwierdzającym konstytucyjność regulacji, jak i po jego wejściu w życie, a odnoszącym się do całej ustawy, określające ponadto ratio legis regulacji oraz rolę sądu powszechnego przy jej stosowaniu.

W ocenie sądów za nieprzypadkowe uznać należy odniesienie przepisów postępowania cywilnego nieprocesowego do postępowania w przedmiocie umieszczenia w Ośrodku. Są one bowiem dostosowane do rozpoznawania spraw, w których w sposób istotny krzyżuje się interes indywidualny stron oraz interes publiczny, dla realizacji których ważny jest fakt wszczęcia postępowania, jego przebieg, badany zakres okoliczności oraz samo rozstrzygnięcie sądu (post. SN z dnia 26 listopada 2017 r., I CSK 821/14, LEX nr 2258051). Jego charakter bowiem znacznie łagodzi zastosowanie zasady kontradyktoryjności (post. SN z dnia 26 listopada 2017 r., I CSK 821/14, LEX nr 2258051), co istotnie wpływa na sposób procedowania sądu. W konsekwencji pozwala to sądom na szczególną drobiazgowość w czynieniu ustaleń faktycznych w sprawie, uzasadnionych, co oczywiste, samą naturą przedmiotu postępowania, związaną z pozbawieniem człowieka wartości go determinującej - wolności osobistej. W ich ocenie szczególna dbałość w tym zakresie nakłada na sądy obowiązki dowodowe, niezależne od inicjatywy dowodowej stron. Na tej podstawie sądy dopuszczają dowody z urzędu, nie ograniczając jednocześnie inicjatywy dowodowej stron postępowania, które mogą dowolnie, według własnego przekonania, wnosić o przeprowadzenie dowodów na wszystkie okoliczności, pozostających $w$ ich ocenie istotnymi dla rozstrzygnięcia sprawy i zgodnymi z ich interesem (post. SA w Rzeszowie z dnia 29 kwietnia 2014 r., I ACa 208/14, LEX nr 2284766). 
Zgodnie $\mathrm{z}$ art. 14 ust. 1 ustawy podstawą oceny zastosowania izolacji postpenalnej jest całokształt okoliczności ustalonych w sprawie, w szczególności uzyskane opinie biegłych (post. SN z dnia 19 stycznia 2017 r., II CSK 459/15, LEX $\mathrm{nr} 2258040$ ) oraz wyniki prowadzonego dotychczas postępowania terapeutycznego oraz możliwości efektywnego poddania się przez tę osobę postępowaniu terapeutycznemu na wolności (post. SN z dnia 10 stycznia 2017 r., V CSK 483/15, LEX nr 2237428). Celem tej regulacji jest zapewnienie zbadania osoby objętej wnioskiem w sposób wszechstronny, obiektywny i bezstronny przez możliwie dużą liczbę samodzielnych i niezależnych biegłych (post. SN z dnia 11 stycznia 2017 r., IV CSK 792/15, LEX nr 2237417). Jeżeli jednostka cierpi zarówno na zaburzenia osobowości, jak i na zaburzenia preferencji seksualnych, sąd obowiązany jest powołać czterech samodzielnych biegłych sądowych: dwóch biegłych lekarzy psychiatrów, jednego biegłego psychologa i jednego biegłego lekarza seksuologa (post. SN z dnia 11 stycznia 2017 r., IV CSK 792/15, LEX nr 2237417). Sąd Najwyższy, podnosząc wymogi określone ustawą, związane z dopuszczaniem i przeprowadzaniem tych dowodów, podkreślał ograniczoną możliwość obiektywnej weryfikacji poczynionych obserwacji za pomocą badań empirycznych, skutkującą większą możliwością popełnienia błędu niż w innych dziedzinach (post. SN z dnia 11 stycznia 2017 r., IV CSK 792/15, LEX nr 2237417). Konieczność prokonstytucyjnej wykładni przepisów przedmiotowej ustawy, także w zakresie, w którym określa ona postępowanie dowodowe, uzasadnia tak restrykcyjną interpretację roli opinii biegłych w tych sprawach. W ocenie SN gwarantuje to możliwie najbardziej rzetelne, wszechstronne i obiektywne zbadanie sprawy (post. SN z dnia 11 stycznia 2017 r., IV CSK 792/15, LEX nr 2237417).

Orzeczenie o umieszczeniu w Ośrodku może zostać wydane jedynie w oparciu o aktualne rozpoznanie zaburzenia psychicznego (post. SN z dnia 31 stycznia 2017 r., I CSK 267/16, LEGALIS nr 1580204). Uznając, że ustawa nakłada na sądy obowiązek szczegółowego określenia okoliczności związanych ze stanem zdrowia uczestnika, w toku postępowania dowodowego, oprócz dowodu z opinii biegłego, dopuszczają one także dowody z protokołów badań psychiatrycznych i opinii sądowo-psychiatrycznych oraz psychologicznych, przeprowadzanych podczas rozpatrywania poszczególnych spraw karnych oraz akt spraw, dotyczących stosowania leczenia wobec uczestnika, podjętego w związku z zaburzeniami preferencji seksualnych, ale także ze szkiców, rysunków, zdjęć i listów (post. SA w Rzeszowie z dnia 29 kwietnia 2014 r., I ACa 208/14, LEX nr 2284766). Za istotny element badania psychiatrycznego, który służy wydaniu przez biegłych psychiatrów rzetelnej i miarodajnej opinii, sądy uznają obserwację w zakładzie psychiatrycznym. Nierzadko biegli wskazują, że bez jej przeprowadzenia w warunkach szpitala psychiatrycznego nie będą w stanie udzielić odpowiedzi, czy charakter zaburzeń lub stopień ich nasilenia wskazują na co najmniej wysokie prawdopodobieństwo popełnienia przez uczestnika czynu zabronionego, określonego przedmiotową ustawą. Nie zastąpi tego dostęp do istniejącej w sprawie dokumentacji medycznej 
(post. SA w Rzeszowie z dnia 28 lutego 2014 r., I ACz 122/14, LEX nr 1438138). Niezależnie od przyjętych przez biegłych środków i wybieranych metod aktualne pozostały wątpliwości środowisk medycznych, wskazujących trudności w określeniu ryzyka popełnienia czynu zabronionego przez jednostkę, rozróżnieniu pojęć „wysokie prawdopodobieństwo” i „bardzo wysokie prawdopodobieństwo”, zwłaszcza w odniesieniu do precyzyjnie określonej przez ustawodawcę kategorii czynów zabronionych, popełnionych z użyciem przemocy lub groźby jej użycia przeciwko życiu, zdrowiu lub wolności seksualnej, zagrożonych karą pozbawienia wolności, których górna granica wynosi co najmniej 10 lat (Więcek-Durańska 2017, 159).

Ocena prognozowanych zachowań wymaga, poza wzięciem pod uwagę opinii biegłych, szczegółowej analizy rodzaju i natężenia zaburzeń psychicznych uczestnika (wyr. SN z dnia 23 marca 2017 r., V CSK 477/16, LEX nr 2255311), przeszłości kryminalnej uwzględniającej ocenę popełnionych czynów, ich motywacji, związku ze stwierdzonymi zaburzeniami psychicznymi, uwzględnienia dotychczasowego przebiegu życia sprawcy, jego aktualnej sytuacji życiowej, wyników postępowania terapeutycznego oraz możliwości jego podjęcia w warunkach wolnościowych (post. SN z dnia 13 stycznia 2016 r., V CSK 455/15, OSNC 2016, nr 11, poz. 133; post. SN z dnia 10 stycznia 2017 r., V CSK 483/15, LEX nr 2237428), obejmuje także chęć poddania się terapii i leczenia farmakologicznego (post. SO w Poznaniu z dnia 27 listopada 2017 r., XIII Ns 90/17, LEX nr 2421673).

Przy ocenie całokształtu okoliczności sprawy za szczególnie istotne sądy uznają nieskuteczność przeprowadzonego dotychczas oddziaływania terapeutycznego, udział w zajęciach psychokorekcyjnych, polegających na indywidualnych i grupowych oddziaływaniach psychologicznych, rozmowach wychowawczych, edukacyjnych, terapii zajęciowej, zajęciach kulturalno-oświatowych i sportowych, gotowość do brania odpowiedzialności za własne zachowania, sposób wchodzenia w relacje interpersonalne, w tym sposób traktowania współwięźniów oraz przełożonych, podejście do oddziaływań terapeutycznych, podejmowanie prób terapii w warunkach wolnościowych, stosunek do funkcjonariuszy policji, utrzymywanie kontaktu z osobami karanymi w przeszłości za popełnienie przestępstw przeciwko wolności seksualnej oraz innymi uznawanymi za osoby wysoce zdemoralizowane, utrzymywanie pracy i pozostawanie w stałym związku (post. SA w Łodzi z dnia 17 grudnia 2014 r., I ACa 1314/14, LEX nr 1659095; zob. Więcek-Durańska 2017, 154-157).

Sądy zwracają uwagę na poszczególne zachowania uczestnika, które mogą świadczyć o braku chęci i determinacji w dążeniu do zmiany osobowości i preferencji, przejawiającej się w negowaniu potrzeby i skuteczności terapii, zniechęcaniu do niej współosadzonych, nieprzestrzeganiu zasad podczas niej obowiązujących i podejmowaniu pozorowanych działań, mających wskazywać na podjęcie terapii (post. SA w Łodzi z dnia 17 grudnia 2014 r., I ACa 1314/14, LEX nr 1659095). 
Jednocześnie wskazują, że same jednak zaburzenia zachowania i emocji, odmowa współpracy w zakresie oddziaływania psychokorekcyjnego i terapeutycznego, które dotąd nie przekroczyły granic wyznaczonych prognozą kryminologiczną, nie mogą być wystarczające dla zastosowania izolacji postpenalnej (post. SN z dnia 13 stycznia 2016 r., V CSK 455/15, LEX nr 1994408).

Dla oceny jej zastosowania decydujące znaczenie ma nie rodzaj i charakter popełnionego przestępstwa, lecz ocena stopnia zagrożenia ponownego jego popełnienia (post. SN z dnia 23 marca 2017 r., V CSK 477/16, LEX nr 2255311). Nie sposób w konsekwencji wykluczyć, że potrzeba jej zastosowania zajdzie, w przypadku osoby odbywającej karę pozbawienia wolności, za przestępstwo niespełniające jednak kryterium najcięższych przestępstw tego rodzaju. Będzie to uzasadnione, gdy u sprawcy zostaną stwierdzone zaburzenia psychiczne o takim charakterze, rodzaju lub nasileniu, które determinują bardzo wysokie prawdopodobieństwo popełnienia przez niego w przyszłości podobnego przestępstwa (post. SN z dnia 23 marca 2017 r., V CSK 477/16, LEX nr 2255311).

Z judykatury wynika ponadto, że kryteriów rozróżnienia pojęć „,wysokiego stopnia prawdopodobieństwa” oraz „bardzo wysokiego stopnia prawdopodobieństwa" dostarczyć może dotychczasowe orzecznictwo, zapadłe na gruncie art. 93c pkt 4 i art. 93g oraz art. $94 \S 1$ ustawy z dnia 6 czerwca 1997 r. - Kodeks karny (Dz.U. z 2017 r., poz. 2204; dalej: k.k.), jak również art. 203 § 1 ustawy z dnia 6 czerwca 1997 r. - Kodeks postępowania karnego (Dz.U. z 2017 r., poz. 1904; dalej: k.p.k.), oraz praktyka ich stosowania, a także wypracowane w tym toku metody wykładni (post. SN z dnia 23 marca 2017 r., V CSK 477/16, LEX nr 2255311). Próby zdefiniowania tych pojęć podjął Sąd Apelacyjny w Katowicach w postanowieniu z dnia 26 lutego 2016 r. (V ACa 13/16, LEX nr 2050477). Bardzo wysokie prawdopodobieństwo oznacza w jego ocenie prawdopodobieństwo tego rodzaju, które „graniczy z pewnością popełnienia pewnej klasy czynów zabronionych". Nie chodzi jednak o wykazanie całkowitej pewności, że takie zdarzenie nastąpi, to bowiem należy uznać za niemożliwe, lecz o uzasadnienie potencjalnej możliwości takiego zachowania się przez jednostkę. Pojęcia prawdopodobieństwa, nawet określonego jako „bardzo wysokiego”, nie należy utożsamiać z pewnością, ponieważ ma ono inne znaczenie. „Wysokie prawdopodobieństwo", będące w realiach przedmiotowej ustawy kategorią przeciwstawną, interpretować należy jako mniejszy stopień prawdopodobieństwa, który jednak zauważalnie przekracza stopień prawdopodobieństwa popełnienia przestępstwa, występujący zwykle wśród ogółu członków społeczeństwa, istotnie przekraczający jedynie teoretyczną i potencjalną możliwość wystąpienia tej okoliczności (LEX nr 2050477).

W toku wykładni przepisów ustawy sądy zwracają uwagę na treść uzasadnienia projektu ustawy, zgodnie z którym zasadniczym celem regulacji jest „poddanie sprawców najpoważniejszych zbrodni z użyciem przemocy lub na tle seksualnym przymusowej terapii”, mającej na celu zapobieżenie 
możliwości popełnienia przez nich w przyszłości podobnych czynów. Odmawiają one ustawie charakteru regulacji karnej, wskazując, że nie dąży ona do wprowadzenia represji w postaci ponownego ukarania sprawcy za ten sam czyn, co mogłoby uzasadniać wątpliwości natury konstytucyjnej (post. SA w Rzeszowie z dnia 29 kwietnia 2014 r., I ACa 208/14, LEX nr 2284766). Sądy podkreślają, że tryb postępowania nieprocesowego, stosowany do orzekania w przedmiocie izolacji postpenalnej, zapewnia każdemu zainteresowanemu, którego wniosek dotyczy,

gwarancję wydania orzeczenia w oparciu o wyniki sądowego postępowania przeprowadzonego w trybie przewidzianym dla spraw cywilnych, co gwarantuje rzetelność oceny zastosowania tak drastycznego w skutkach środka, jak ewentualna izolacja w Ośrodku (post. SA w Rzeszowie z dnia 29 kwietnia 2014 r., I ACa 208/14, LEX nr 2284766).

Sądy odmawiają jednocześnie rozszerzającej wykładni art. 1 ust. 2 ustawy, wskazującej na zaburzenia psychiczne, zaburzenia osobowości i zaburzenia preferencji seksualnych jako przesłanki uzasadniające stosowanie izolacji postpenalnej, podkreślając, że kategoria ta nie obejmuje chorób psychicznych, na które mogą cierpieć uczestnicy. W przypadku zatem np. schizofrenii paranoidalnej sądy zauważają konieczność stosowania przymusowego leczenia na podstawie ustawy o ochronie zdrowia psychicznego (post. SA w Rzeszowie z 29 kwietnia 2014 r.). Tym samym w ocenie sądów brak jest podstaw do przenoszenia medycznych przesłanek ubezwłasnowolnienia, traktującego choroby psychiczne jako jedną z form zaburzeń psychicznych, na grunt przedmiotowej ustawy jako regulacji szczególnej, odnoszącej się jedynie do specjalnej kategorii osób, co do których istnieje definicja legalna. Zgodnie z nią ustawę stosować należy do osób, u których w trakcie wykonywania kary pozbawienia wolności „występowały zaburzenia w postaci upośledzenia umysłowego, zaburzenia osobowości lub zaburzenia preferencji seksualnych". Wyszczególnienie to uznaje się za wyczerpujące i świadomie pomijające chorobę psychiczną (post. SN z dnia 16 kwietnia 2015 r., I CSK 825/14, LEX nr 1677120). Co ciekawe, Sąd Najwyższy niedopuszczalność wykładni rozszerzającej przedmiotowej ustawy, odnoszącej się do form ograniczenia lub pozbawienia wolności, uzasadnia represyjno-izolacyjnym charakterem ustawy oraz orzecznictwem Trybunału Konstytucyjnego, nakazującym ścisłą interpretacją przepisów o sankcjach w prawie karnym, znajdującym zastosowanie do wszystkich uregulowań o charakterze represyjnym, sankcjonująco-dyscyplinarnym (post. SN z dnia 16 kwietnia 2015 r., I CSK 825/14, LEX 1677120). W ocenie SN przepisy ustawy, w tym w szczególności określające jej zakres podmiotowy, interpretować należy w sposób ścisły i gramatyczny (post. SN z dnia 16 kwietnia 2015 r., I CSK 825/14, LEX nr 1677120). 


\section{DYREKTYWY INTERPRETACJI USTAWY O IZOLACJI POSTPENALNEJ WYNIKAJĄCE Z ORZECZNICTWA SĄDU NAJWYŻSZEGO}

W postanowieniu Sądu Najwyższego z dnia 13 stycznia 2016 r. (V CSK 455/15, LEX nr 1994408), wydanym przed wyrokiem Trybunału Konstytucyjnego, potwierdzającym zgodność przepisów z ustawą zasadniczą, SN podkreślał obowiązek spoczywający na sądach powszechnych interpretowania ustaw w zgodzie z Konstytucją oraz dążenia do zapewnienia im znaczenia, które pozostaje zgodne $\mathrm{z}$ zasadami przewidzianymi w ustawie zasadniczej, ale także $\mathrm{w}$ prawie międzynarodowym wiążącym Polskę oraz z ich aksjologicznym uzasadnieniem.

W zakresie ustawy o izolacji postpenalnej za szczególnie istotną SN uznał zasadę interpretacji na rzecz poszerzania praw i wolności, in dubio pro libertate, zgodnie z którą żadna z indywidualnych spraw obywateli nie może być rozstrzygana w sposób naruszający obowiązek respektowania godności ludzkiej i wynikającego z tej godności prawa do wolności, słusznie wychodząc z założenia, że wszystkie ograniczenia praw jednostki muszą być konieczne w demokratycznym państwie dla jego bezpieczeństwa lub porządku publicznego, bądź dla ochrony środowiska, zdrowia i moralności publicznej, albo wolności i praw innych osób, przy czym i wtedy nie mogą naruszać ich istoty.

W ocenie SN wyjście poza te granice, także w toku wykładni przepisów prawa, nie może być w demokratycznym państwie prawnym akceptowane. Odnosząc tezy te do ustawy o izolacji postpenalnej, SN wskazywał, że sądy nie mogą poprzestać na ustaleniu faktów i odpowiadającej im podstawy prawnej oraz ich kwalifikowaniu z uwzględnieniem normy prawnej. Zobowiązane są uwzględniać także, że skierowanie do Ośrodka ma charakter bezterminowy i izolacyjny, a placówka, jakkolwiek ma na celu stosowanie programów terapeutycznych, nie jest placówką leczniczą. Nieostrość pojęć, przy pomocy której ustawodawca skonstruował przesłanki dopuszczalności orzekania izolacji postpenalnej, każe odwołać się $\mathrm{w}$ toku ich stosowania do niepewnych prognoz kryminologicznych. Środki izolacji stosowane są ponadto w oderwaniu od uprzednio popełnionych czynów oraz przy braku medycznych przesłanek do przymusowej terapii. SN wskazał, że do zadań sądu meriti należy uwzględnienie dobra osoby z zaburzeniami psychicznymi, nie zaś realizacja szeroko rozumianego interesu społecznego, i rozważenie, czy środek zabezpieczający określony ustawą nie zmierza do obejścia bezwzględnych zakazów prawa karnego, związanych z niedopuszczalnością karania dwa razy za ten sam czyn oraz prewencyjnym pozbawianiem człowieka wolności oraz czy nie należy uwzględniać zasad odpowiednio go dotyczących.

Po wyroku Trybunału Konstytucyjnego, który potwierdził zgodność aktu prawnego z Konstytucją, Sąd Najwyższy wskazał, że ustawy oraz zapadłe na jej gruncie orzeczenie TK wiążą sądownictwo powszechne oraz SN, szczególnie w świetle nowelizacji ustawy z dnia 20 lutego 2015 r. ustawy o zmianie ustawy 
- Kodeks karny oraz niektórych innych ustaw (Dz.U. z 2015 r., poz. 396), która znacząco poprawiła istniejącą regulację (post. SN z dnia 10 sierpnia 2017 r., I CSK 328/17, LEX nr 2361217). Wyrok TK nie wpłynął jednak na aktualność postanowienia SN i wskazanych w nim dyrektyw interpretacyjnych ustawy.

\section{STANDARD EUROPEJSKIEGO TRYBUNALU PRAW CZLOWIEKA}

W toku prac legislacyjnych przedmiotem swoich analiz projektodawca uczynił orzecznictwo Europejskiego Trybunału Praw Człowieka w zakresie przymusowej izolacji jednostek, szeroko cytując je w uzasadnieniu ustawy, dlatego konieczne wydaje się zbadanie dorobku trybunału w tym zakresie i dokonanie oceny istniejącej regulacji w świetle obowiązującego orzecznictwa. W pierwszej kolejności wskazać należy, że jakkolwiek ETPC nie wypracował samodzielnego standardu, odnoszącego się do prewencyjnego pozbawienia wolności jednostek stwarzających zagrożenie dla praw i wolności innych osób, tak jednocześnie nigdy nie zakwestionował on samej możliwości prewencyjnej izolacji sprawców przestępstw po odbyciu przez nich kary pozbawienia wolności. Rozważając dopuszczalność izolacji prewencyjnej, trybunał podkreślał, że ustanawiające ją regulacje winny czynić zadość wymogom sformułowanym w art. 5 i 7 Konwencji o Ochronie Praw Człowieka i Podstawowych Wolności z dnia 4 listopada $1950 \mathrm{r}$. (Dz.U. z 1993 r. Nr 61, poz. 284; dalej: Konwencja, EKPC), określającym warunki legalnego pozbawienia wolności jednostki i rygory retroaktywnego stosowania przepisów karnych.

Zagadnienie izolacji postpenalnej było rozważane w orzecznictwie ETPC przede wszystkim w związku ze sprawami niemieckimi, dotyczącymi stosowania izolacji prewencyjnej z mocą wsteczną i bez określenia czasu jej trwania. W sprawie M. v. Niemcy ETPC sformułował dwie istotne zasady, aktualizujące się przy rozważaniu zgodności ustawy o izolacji postpenalnej z Konwencją. Trybunał stwierdził, że o dopuszczalności zastosowania tego środka mogą decydować wyłącznie przepisy obowiązujące w momencie popełnienia przez sprawcę czynu zabronionego pod groźbą kary (Skowron 2012, 41-47). Zwrócił także uwagę na podobieństwo zachodzące pomiędzy tym środkiem zabezpieczającym a karą. Trybunał wskazał, że jako legalny może być uznany tylko taki środek izolacyjny, który zostanie uzasadniony spełnieniem warunków albo z art. 5 ust. 1 lit. a) EKPC (pozbawienie wolności w wyniku skazania przez właściwy sąd), albo $\mathrm{z}$ art. 5 ust. 1 lit. e) EKPC - zgodnego z prawem pozbawienia wolności osoby umysłowo chorej (zob. wyr. ETPC z dnia 9 stycznia 2012 r., w sprawie Kronfeldner v. Niemcy, skarga nr 21906/09).

Art. 5 ust. 1 lit. a) Konwencji dopuszcza zgodne z prawem pozbawienie wolności przez właściwy sąd, przy czym zgodnie z oceną trybunału, aby można było mówić o „skazaniu”, konieczne jest stwierdzenie „winy” po tym, jak oskarżony 
zostanie uznany za sprawcę czynu zabronionego pod groźbą kary (wyr. ETPC z dnia 17 grudnia 2009 r., w sprawie M v. Niemcy, skarga nr 19359/0, § 88 i § 96). Chociaż za desygnat pojęcia ,skazania” nie można uznać stosowania izolacji postpenalnej, nie jest ona bowiem związana ze stwierdzeniem ,winy” i popełnieniem przez jednostkę czynu karalnego (wyr. ETPC z dnia 17 grudnia 2009 r., w sprawie M v. Niemcy, skarga nr 19359/0, § 95 i § 96), to musi ona zostać zastosowana „w wyniku” skazania, w rozumieniu art. 5 ust. 1 lit. a). Między zastosowaniem izolacji postpenalnej, a ,skazaniem” musi zaistnieć związek przyczynowo-skutkowy (wyr. ETPC z dnia 17 grudnia 2009 r., w sprawie M v. Niemcy, skarga nr 19359/0, § 88 i § 96). Jeżeli sąd w wyroku skazującym zastosuje wobec sprawcy izolację po odbyciu przez niego kary lub co najmniej możliwość taką zasygnalizuje, będzie można uznać, że wymagany orzecznictwem ETPC związek przyczynowo-skutkowy zaistniał. Samo zasygnalizowanie istnienia wyroku skazującego sprawcę w decyzji dotyczącej zastosowania izolacji postpenalnej, gdy decyzja ta została podjęta w trakcie odbywania kary pozbawienia wolności (wyr. ETPC z dnia 13 stycznia 2011 r. w sprawie Haidn v. Niemcy, skarga nr 6587/04, § 88), nie wywoła takiego skutku.

Odmiennie ETPC ocenia dopuszczalność stosowania izolacji jednostki na podstawie art. 5 ust. 1 lit. e) EKPC, który przewiduje zgodne z prawem pozbawienie wolności osoby w celu zapobieżenia szerzenia przez nią choroby zakaźnej albo osoby umysłowo chorej, alkoholika, narkomana lub włóczęgi. W sprawie W. v. Niderlandy z 1979 r. trybunał wskazał, że stały postęp nauk medycznych uniemożliwia jednoznaczne zdefiniowanie pojęcia osoby „chorej umysłowo”. Zauważył jednocześnie, że osobą chorą psychicznie w rozumieniu tego przepisu będzie ta, która wykazuje jedynie zaburzenia osobowości, nie będąc jednocześnie dotkniętą chorobą psychiczną w ścisłym tego słowa znaczeniu. Zaburzenia tego rodzaju muszą zostać jednak potwierdzone przez wykwalifikowanego biegłego, mieć istotny charakter i podlegać permanentnej kontroli w czasie stosowania izolacji terapeutycznej. Aby zaburzenie umysłowe mogło być uznane za uzasadniające pozbawienie wolności, konieczne jest ponadto wykazanie, że izolacja danej osoby jest niezbędna ze względu na niezbędność poddania jej terapii, leczenia farmakologicznego lub innego leczenia klinicznego, prowadzącego do wyleczenia bądź przynajmniej złagodzenia jej stanu (zob. wyr. ETPC z dnia 4 kwietnia 2000 r. w sprawie Witold Litwa v. Poland, skarga nr 26629/95, pkt 60; wyr. ETPC z dnia 20 lutego 2003 r. w sprawie Hutchison Reid v. the United Kingdom, skarga nr 50272/99, pkt 52, ECHR 2003-IV.; za Królikowski, Sakowicz 2013, 28).

W ocenie trybunału nie jest możliwa dalsza izolacja sprawców, którzy stwarzają wysokie ryzyko ponownego popełnienia przestępstwa, jeżeli nie zostało wykazane w toku prowadzonego postępowania karnego, że sprawca nie jest w pełni poczytalny z uwagi na występujące u niego zaburzenia osobowości, gdy skierowania do miejsca izolacji dokonuje organ właściwy w sprawach karnych, a warunki izolacji są zbliżone do sposobu wykonania kary pozbawienia wolności, także 
jeżeli jednostce nie zostało zapewnione odpowiednie postępowanie terapeutyczne, które miałoby na celu wyeliminowanie grożącego z jej strony niebezpieczeństwa popełnienia kolejnych przestępstw i które pozwoliłoby na odróżnienie tego środka od kary pozbawienia wolności (Królikowski, Sakowicz 2013, 28).

W sprawie K. v. Niemcy trybunał wskazał na konieczność zapewnienia krajowej regulacji na tyle elastycznego charakteru, by umożliwić Państwu-Stronie jej stosowanie wobec zaburzonych sprawców, bazując na zindywidualizowanej ocenie każdego przypadku (Królikowski, Sakowicz 2013, 24). W powyższej sprawie trybunał zwrócił uwagę na wymagania dotyczące art. 5 ust. 1 lit. e) Konwencji. Po pierwsze, zaburzenie umysłowe musi zostać wiarygodnie udowodnione na podstawie obiektywnych opinii lekarskich. Po wtóre, nieprawidłowość musi być takiego rodzaju lub o takim stopniu, który uzasadnia przymusowe pozbawienie wolności. Po trzecie, warunkiem hospitalizowania w warunkach zamkniętych jest utrzymywanie się zaburzeń przez cały okres pozbawienia wolności (wyr. ETPC z dnia 9 stycznia 2012 r. w sprawie Kronfeldner v. Niemcy, skarga nr 21906/09, § 45). Podsumowując, przy pozbawieniu wolności na podstawie art. 5 ust. 1 lit. e) EKPC nie chodzi o, jak ma to miejsce w przypadku art. $7 \mathrm{i}$ art. 5 ust. 1 zdanie 2 lit. a) EKPC, pozbawienie wolności z powodu przestępstwa popełnionego w przeszłości ani o związane z nim skazanie, ale o pozbawienie wolności na podstawie teraźniejszego stanu, przy należytym wykazaniu występowania określonych zaburzeń (wyr. ETPC z 24 października 1979 r. w sprawie Winterwerp v. Niderlandy, pkt 40; wyr. ETPC z dnia 5 listopada 1981 r. w sprawie X v. the United Kingdom, skarga nr 7215/75, pkt 43; wyr. ETPC z dnia 5 października 2004 r. w sprawie H.L. v. the United Kingdom, skarga nr 45508/99, pkt 98; wyr. ETPC z dnia 24 marca 2009 r. w sprawie Puttrus v. Germany, skarga nr 1241/06; za Królikowski, Sakowicz 2013, 29).

\section{PODSUMOWANIE}

Analiza orzecznictwa sądów powszechnych oraz Sądu Najwyższego wskazuje, że część wątpliwości zgłaszanych przez doktrynę prawa konstytucyjnego oraz karnego okazała się nieuzasadniona. Nowelizacja nadała ustawie charakter epizodyczny, odnosząc jej stosowanie do osób skazanych za czyn popełniony przed dniem wejścia w życie nowelizacji, tym samym istotnie zawężając krąg podmiotowy jej adresatów. Warunkuje ona stosowanie internacji aktualnością zaburzeń psychicznych, które muszą ponadto cechować się takim stopniem natężenia lub być takiego rodzaju, by uzasadniać przymusowe pozbawienie wolności. Zaburzenia te koniecznie wykazać należy wiarygodnie udowodnionymi obiektywnymi opiniami lekarskimi. Konieczność weryfikacji stanu zdrowia jednostki oraz analizy wyników postępowania terapeutycznego nie rzadziej niż raz na 6 miesięcy spełnia także warunek utrzymywania się zaburzeń psychicznych przez cały okres 
pozbawienia wolności (wyr. ETPC z dnia 13 stycznia 2011 r. w sprawie Kallweit przeciwko Niemcom, skarga nr 17792/07).

Istotne wątpliwości wciąż budzi sposób określenia przesłanek, uzasadniających stosowanie izolacji postpenalnej. Ustawodawca posłużył się przy ich determinowaniu pojęciami niedookreślonymi, które w naszej opinii pozostawiają organom stosującym prawo zbyt duży zakres marginesu oceny, stwarzają istotne pole do nadużyć i jednocześnie z punktu widzenia wykładni prawa nie dają się łatwo zdefiniować.

Rozróżnienie zakresu pojęć ,wysokie prawdopodobieństwo” i ,bardzo wysokie prawdopodobieństwo", odnoszonych do antycypowanego zachowania jednostki, u której, zgodnie z ustawą, występowały zaburzenia psychiczne w postaci upośledzenia umysłowego, zaburzenia osobowości lub zaburzenia preferencji seksualnych w trakcie postępowania wykonawczego, jest niemożliwe i zdaje się nie poddawać ocenie. Ustawa nie wskazuje żadnych przesłanek mających ułatwić sędziemu i biegłym, wydającym opinie w sprawie, dokonanie rozstrzygnięcia w tym przedmiocie, przenosząc na biegłego ciężar odpowiedzialności za określenie postawy sprawcy i jego prognozy kryminologicznej i jednocześnie znacząco wpływając na zakres oceny sędziego w danej sprawie. Dotychczasowe orzecznictwo sądów powszechnych i Sądu Najwyższego nie doprowadziło do ich zdefiniowania i doprecyzowania.

Praktyka stosowania prawa zauważa niedostatki regulacji i, wykorzystując możliwości, jakie stwarza postępowanie nieprocesowe ograniczające zasadę kontradyktoryjności i zezwalające na podejmowanie przez sąd inicjatywy w przedmiocie dopuszczania oraz przeprowadzania dowodów, dąży do zniwelowania negatywnych konsekwencji nieprecyzyjności przepisów. Sądy meriti, dostrzegając wagę przedmiotu postępowania, związanego z pozbawieniem wolności jednostki, wykazują daleko idący aktywizm. Przejawia się on w szerokim katalogu okoliczności, które biorą pod uwagę, oceniając prawdopodobieństwo popełniania czynu zabronionego z użyciem przemocy lub groźbą jej użycia. Dążąc tym samym do ustalenia wszystkich istotnych dla sprawy elementów stanu faktycznego, szczegółowo ustalają przebieg postępowania terapeutycznego i zachowania sprawcy w zakładzie karnym oraz powołują biegłych różnych specjalizacji w skomplikowanych, wielowątkowych sprawach, możliwie precyzyjnie formułując tezy dowodowe.

Wszystkie te działania mające charakter procesowy niewątpliwie dążą do indywidualizacji sytuacji jednostek i mają na celu zapewnienie im gwarancji ochrony podstawowych praw i wolności. Uznać je należy za sposób wykonywania przez sądy ich konstytucyjnej roli strażnika statusu jednostki opartego na zasadzie godności, polegającej na ochronie człowieka przed arbitralnym działaniem organów władzy publicznej, wyrażającej troskę o zachowanie właściwej proporcji przy stosowaniu ograniczeń praw i wolności oraz ważeniu pozostających w sporze wartości chronionych prawnie, gwarantującej jednostce należytą ochronę. 
Taka gotowość sądów, jakkolwiek znajdująca swoje uzasadnienie w aksjologii ustawy zasadniczej, nie zwalnia jednak ustawodawcy zwykłego z konieczności poszanowania zasad prawidłowej legislacji, wypracowanych przez Trybunał Konstytucyjny, z dążenia do uchwalania prawa, którego skutki dają się przewidzieć przez jednostkę, a także konieczności rozważnego i przemyślanego stosowania instytucji przymusowej izolacji jednostek, wywodzonej przez trybunał strasburski. Dyrektywy te mają charakter fundamentalny; szczególnie w sytuacji, gdy przedmiotem wprowadzanych regulacji jest wartość o tak doniosłym charakterze, jak wolność człowieka.

\section{BIBLIOGRAFIA}

Bocheński, Maciej. 2014. „Populizm penalny w polskim wydaniu - rzecz o kryminologicznej problematyce ustawy o postępowaniu wobec osób stwarzających zagrożenie”. e-Czasopismo Prawa Karnego i Nauk Penalnych 2. http://www.czpk.pl/dokumenty/publikacje/2014/03/2-2014-M. Bochenski-Populizm_penalny_w_polskim_wydaniu-rzecz_o_kryminologicznej_problematyce_ ustawy_o_postepowaniu_wobec_osob_stwarzajacych_zagrozenie.pdf [dostęp 15.02.2018].

Domański, Marek. 2013. „Opinia dotycząca projektu ustawy o postępowaniu wobec osób z zaburzeniami psychicznymi stwarzających zagrożenie życia, zdrowia lub wolności seksualnej innych osób". Przed Pierwszym Czytaniem 2: 19-20. http://orka.sejm.gov.p1/WydBAS.nsf/0/C9C9D 2ECF427AB48C1257C3900505560/\$file/ppc_2-2013.pdf [dostęp 15.02.2018].

Heitzman, Janusz. 2013. „Ekspertyza projektu ustawy o postępowaniu wobec osób z zaburzeniami psychicznymi stwarzających zagrożenie życia, zdrowia lub wolności seksualnej innych osób". Przed Pierwszym Czytaniem 2: 7-11. http://orka.sejm.gov.pl/WydBAS.nsf/0/C9C9D2ECF42 7AB48C1257C3900505560/\$file/ppc_2-2013.pdf [dostęp 15.02.2018].

Królikowski, Michał, Andrzej Sakowicz. 2013. „Granice legalności postpenalnej detencji sprawców niebezpiecznych”. Forum Prawnicze 5: 17-34. http://admin.forumprawnicze.eu/attachments/ article/42/krolikowski_sakowicz.pdf [dostęp 15.02.2018].

Kruszyński, Piotr, Marcin Warchoł. 2013. „Opinia prawna na temat rozwiązań zaproponowanych w rozdziale 1 rządowego projektu ustawy o postępowaniu wobec osób z zaburzeniami psychicznymi stwarzających zagrożenie życia, zdrowia lub wolności seksualnej innych osób, w szczególności dotyczących katalogu osób objętych propozycją i jakie konsekwencje mogą wystąpić w przypadku zastosowania tak szerokiego katalogu osób". Przed Pierwszym Czytaniem 2: 27. http://orka.sejm.gov.p1/WydBAS.nsf/0/C9C9D2ECF427AB48C1257C390050556 0/\$file/ppc_2-2013.pdf [dostęp 15.02.2018].

Piotrowski, Ryszard. 2013. „Opinia w przedmiocie zgodności z Konstytucją RP projektu ustawy o postępowaniu wobec osób z zaburzeniami psychicznymi stwarzających zagrożenie życia, zdrowia lub wolności seksualnej innych osób”. Przed Pierwszym Czytaniem 2: 38. http://orka. sejm.gov.p1/WydBAS.nsf/0/C9C9D2ECF427AB48C1257C3900505560/\$file/ppc_2-2013. pdf [dostęp 15.02.2018].

Płatek, Monika. 2013. „Opinia na temat poselskiego projektu ustawy o zmianie ustawy - Kodeks karny oraz ustawy - Kodeks karny wykonawczy oraz rządowego projektu ustawy o postępowaniu wobec osób z zaburzeniami psychicznymi stwarzających zagrożenie życia, zdrowia lub wolności seksualnej innych osób”. Przed Pierwszym Czytaniem 2: 47. http://orka.sejm.gov. pl/WydBAS.nsf/0/C9C9D2ECF427AB48C1257C3900505560/\$file/ppc_2-2013.pdf [dostęp 15.02.2018]. 
Skowron, Magdalena. 2012. „Prawa człowieka a postpenalna izolacja sprawcy w Polsce - rozważania na tle wyroków ETPCz w sprawach niemieckich”. Europejski Przegląd Sądowy 8: 41-47.

Sokolewicz, Wojciech, Marek Zubik. 2016. „Komentarz do art. 2”. W Konstytucja Rzeczypospolitej Polskiej. Komentarz. T. 1. Wyd. 2. Red. Leszek Garlicki, Marek Zubik. 94-173. Warszawa: Wydawnictwo Sejmowe.

Więcek-Durańska, Anna. 2017. „Praktyka orzecznicza wykonywania nadzoru prewencyjnego oraz umieszczenia w Krajowym Ośrodku Zapobiegania Zachowaniom Dyssocjalnym osób stwarzających zagrożenie”. Prawo w Działaniu 30: 139-172. https://www.iws.org.pl/pliki/ files/Anna\%20Wi\%C4\%99cek\%20-\%20Dura\%C5\%84ska\%20-\%2030\%20PwD.pdf [dostęp 25.08.2018].

Zalasiński, Tomasz. 2008. Zasada prawidłowej legislacji w pogladach Trybunału Konstytucyjnego. Warszawa: Wydawnictwo Sejmowe.

\section{Akty prawne}

Konstytucja Rzeczpospolitej Polskiej z dnia 2 kwietnia 1997 r. (Dz.U. z 1997 r. Nr 78, poz. 483).

Konwencja o Ochronie Praw Człowieka i Podstawowych Wolności z dnia 4 listopada $1950 \mathrm{r}$. (Dz.U. z 1993 r. Nr 61, poz. 284).

Ustawa z dnia 7 grudnia 1989 r. o amnestii (Dz.U. z 1989 r. Nr 64, poz. 390).

Ustawa z dnia 22 listopada 2013 r. o postępowaniu wobec osób z zaburzeniami psychicznymi stwarzających zagrożenie życia, zdrowia lub wolności seksualnej innych osób (Dz.U. z 2014 r., poz. 24).

Ustawa z dnia 20 lutego 2015 r. o zmianie ustawy - Kodeks karny oraz niektórych innych ustaw (Dz.U. z 2015 r., poz. 396).

\section{Orzecznictwo}

Postanowienie SA w Katowicach z dnia 26 lutego 2016 r., V ACa 13/16, LEX nr 2050477.

Postanowienie SA w Łodzi z dnia 17 grudnia 2014 r., I ACa 1314/14, LEX nr 1659095.

Postanowienie SA w Rzeszowie z dnia 28 lutego 2014 r., I ACz 122/14, LEX nr 1438138.

Postanowienie SA w Rzeszowie z dnia 29 kwietnia 2014 r., I ACa 208/14, LEX nr 2284766.

Postanowienie SN z dnia 16 kwietnia 2015 r., I CSK 825/14, LEX nr 1677120.

Postanowienie SN z dnia 13 stycznia 2016 r., V CSK 455/15, LEX nr 1994408.

Postanowienie SN z dnia 10 stycznia 2017 r., V CSK 483/15, LEX nr 2237428.

Postanowienie SN z dnia 11 stycznia 2017 r., IV CSK 792/15, LEX nr 2237417.

Postanowienie SN z dnia 19 stycznia 2017 r., II CSK 459/15, LEX nr 2258040.

Postanowienie SN z dnia 31 stycznia 2017 r., I CSK 267/16, LEGALIS nr 1580204.

Postanowienie SN z dnia 23 marca 2017 r., V CSK 477/16, LEX nr 225531.

Postanowienie SN z dnia 10 sierpnia 2017 r., I CSK 328/17, LEX nr 2361217

Postanowienie SN z dnia 26 listopada 2017 r., I CSK 821/14, LEX nr 2258051.

Postanowienie SO w Poznaniu z dnia 27 listopada 2017 r., XIII Ns 90/17, LEX nr 2421673.

Postanowienie TK z dnia 27 kwietnia 2004 r., P 16/03, OTK ZU-A 2004, nr 4, poz. 36.

Uchwała TK z dnia 6 listopada 1991 r., W 2/91, OTK ZU 1991, poz. 20.

Wyrok ETPC z dnia 17 grudnia 2009 r. w sprawie M v. Niemcy, skarga nr 19359/0.

Wyrok ETPC z dnia 13 stycznia 2011 r. w sprawie Haidn v. Niemcy, skarga nr 6587/04.

Wyrok ETPC z dnia 13 stycznia 2011 r. w sprawie Kallweit przeciwko Niemcom, skarga nr 17792/07.

Wyrok ETPC z dnia 9 stycznia 2012 r. w sprawie Kronfeldner v. Niemcy, skarga nr 21906/09.

Wyrok TK z dnia 10 listopada 1998 r., K 39/97, OTK ZU 1998, nr 6, poz. 99.

Wyrok TK z dnia 24 lutego 2003 r., K 28/02, OTK ZU 2003-A, nr 2, poz. 13. 
Wyrok TK z dnia 16 grudnia 2003 r., SK 34/03, OTK ZU 2003-A, nr 9, poz. 102. Wyrok TK z dnia 24 czerwca 2008 r., SK 16/06, OTK ZU 2008-A, nr 5, poz. 85. Wyrok TK z dnia 22 czerwca 2010 r., SK 25/08, OTK ZU 2010-A, nr 5, poz. 51.

\title{
Inne źródła
}

Opinia Polskiego Towarzystwa Psychiatrycznego z dnia 25 stycznia 2013 r. http://legislacja.rcl.gov. $\mathrm{pl} /$ docs//2/128528/128531/128534/dokument65493.pdf [dostęp 16.02.2018].

Opinia Polskiego Towarzystwa Psychologicznego z dnia 25 stycznia 2013 r. http://legislacja.rcl.gov. pl/docs//2/128528/128531/128534/dokument67996.pdf [dostęp 16.02.2018].

Uzasadnienie projektu ustawy z dnia 22 listopada 2013 r. o postępowaniu wobec osób z zaburzeniami psychicznymi stwarzających zagrożenie życia, zdrowia lub wolności seksualnej innych osób, druk nr 1577. http://www.sejm.gov.pl/Sejm7.nsf/druk.xsp?nr=1577\&fbclid=IwAR3pZyX-rSgUJX-4je-vbL9RUen2oAFYHa9SiO6e7_2X_SMcjfGo4AlPa5c [dostęp 16.02.2018].

\author{
Franciszek Jędras, Katarzyna Grabarczyk
}

\section{PREMISES FOR POST-PENAL ISOLATION. CONSIDERATIONS BASED ON THE CASE LAW OF COMMON COURTS AND THE SUPREME COURT}

\begin{abstract}
The discussed Act introduced an institution of post-penal isolation into the Polish legal system. The scientific community widely criticised this regulation at the stage of the legislative process and assessed it as being hasty and ill-conceived. The statue was alleged to be only a response to the social demand arising out of fear of prison release of the extremely dangerous perpetrators who had been serving the sentence of 25 years' imprisonment. Doubts of the doctrine were focused on the manner of defining the subjective scope of the Act. It was assessed as imprecise and arousing fundamental interpretative doubts which may result in its provisions being referred to the overly wide range of addresses. The analysis of the case-law of common courts and the Supreme Court indicates, however, that the regulation is applied with great caution and the courts use the procedural possibilities resulting from the non-contentious civil procedure to prevent unauthorized interference with human freedom and its status as a legal entity.
\end{abstract}

Keywords: post-penal isolation, the principle of certainty in law, forced isolation of perpetrators, constitutional law, offences against life, health and sexual freedom of others. 